Research Article

\title{
Synthesis of Alpha-GammaAluminum Oxide Nanocomposite via Electrochemical Method for Antibacterial Activity
}

\author{
Ahmed Mahdi Rheima ${ }^{1}$, Ahmed Abed Anber $^{2}$, Hussein Ismael Abdullah ${ }^{3}$, Ahmad Hussein Ismail ${ }^{3}$ \\ ${ }^{1}$ Department of Chemistry, College of Science,University of Wasit,Kut, Iraq. \\ ${ }^{2}$ Department of Student Affairs and Registration, Al-Karkh University of Science, Baghdad, Iraq. \\ ${ }^{3}$ Department of Chemistry, College of Science, Mustansiriyah University, Baghdad, Iraq. \\ Corresponding author. E-mail: arahema@uowasit.edu.iq
}

Received: Apr. 27, 2020; Accepted: Aug. 28, 2020; Published: Dec. 25, 2020

Citation: Ahmed Mahdi Rheima, Ahmed Abed Anber, Hussein Ismael Abdullah, and Ahmad Hussein Ismail, Synthesis of Alpha-Gamma Aluminum Oxide Nanocomposite via Electrochemical Method for Antibacterial Activity. Nano Biomed. Eng., 202 I, I 3(I): I-5.

DOI: 10.5101/nbe.v13i1.p1-5.

\begin{abstract}
This work was devoted to synthesizing $\alpha-\gamma \mathrm{Al}_{2} \mathrm{O}_{3}$ nanocomposite by the electrolysis method. A plate of aluminum was used as the anode, while the graphite rod was used as the counter electrode (cathode). The structure and morphology were investigated and characterized by X-ray diffraction (XRD) and transmission electron microscopy (TEM). The results indicated the average size of $\alpha-\gamma \mathrm{Al}_{2} \mathrm{O}_{3}$ nanocomposite was smaller than $10 \mathrm{~nm}$. The value of inhibition zone indicated the nanocomposite's effect on different bacteria. The results demonstrated the newly synthesized nanocomposite as promising antimicrobial agents against bacteria.
\end{abstract}

Keywords: $\alpha-\gamma \mathrm{Al}_{2} \mathrm{O}_{3}$ nanocomposite, TEM, Electrochemical method, Antibacterial activity

\section{Introduction}

Nanotechnology is developing as quickly with its application in science for the engineering of new materials at the nanoscale [1-7]. The possess of Nanoparticles are different chemical properties when compared to bulk kinds of similar chemical composition [8-11]. Nanotechnology has extensive interests, especially in the medical, industrial, and environmental fields [12-15]. Metal oxide nanoparticles have exhibited better stability, low poisonousness, high immovability, and selectivity associated with organic compounds [16-18]. Moreover, the particle size of such is responsible for the changes in their basic physical and chemical properties.
These particles exhibit remarkable applications in catalysis, drug delivery, water treatment, sensor devices, semiconductor materials, and solid oxide fuels [19, 20]. Aluminum oxide nanoparticles have significant industrial applications [21], and they has many usages like abrasive material, as an absorbent in heterogeneous catalysis and metal-matrix composites as a biomaterial and reinforcements [22, 23]. A wide range of applications of $\mathrm{Al}_{2} \mathrm{O}_{3}$ was employed, such as sensors, electronics devices, antimicrobial, catalyst, and so on [24, 25]. Here it is many forms of crystallographic phases, on which $\gamma$ and $\alpha$ forms were used for application because of its different features. The high surface area of $\gamma-\mathrm{Al}_{2} \mathrm{O}_{3}$ lead to it useful for catalyst related application [26, 27], whereas 
the polycrystalline $\alpha-\mathrm{Al}_{2} \mathrm{O}_{3}$ is widely used for glassceramic application [28, 29]. It is outstanding from information in writing that for acquiring items of thick nanocrystalline $\mathrm{Al}_{2} \mathrm{O}_{3}$, both phases change from $\gamma$ to $\alpha$ phase must be prevented or nanocrystalline $\alpha-\mathrm{Al}_{2} \mathrm{O}_{3}$ powders must be utilized [30-32]. Aluminum oxide nanoparticles can be the preparation by several methods containing electrolysis, hydrothermal, solgel, spray pyrolysis, plasma sputtering, laser ablation, and pulse laser deposition [33-37]. The purpose of this work is to synthesis a novel nanocomposite of two phases of aluminum oxide (alpha and gamma) by electrolysis method, which is considered a new with a nanocomposite because whole methods were prepared one phase structure. There is not considered an important research effort on the antibacterial of $\alpha-\gamma \mathrm{Al}_{2} \mathrm{O}_{3}$ nanocomposite. Thus the result can be considered high, and the work can be a good attempt to syntheses $\alpha-\gamma \mathrm{Al}_{2} \mathrm{O}_{3}$ nanocomposite by electrochemical method and employ in such an important application.

\section{Experimental Chemicals and reagents}

No further purification, both chemicals were of analytical reagent grades and used as obtained.

\section{Synthesis of $\alpha-\gamma \mathrm{Al}_{2} \mathrm{O}_{3}$ nanocomposite}

$\alpha-\gamma \mathrm{Al}_{2} \mathrm{O}_{3}$ nanocomposite have been synthesized by the electrolysis method, Fig. 1, using $150 \mathrm{ml}$ of $0.08 \mathrm{M} \mathrm{KOH}$ at $25{ }^{\circ} \mathrm{C}$ as the electrolyte. A rectangular aluminum plate $(50 \mathrm{~mm} \times 25 \mathrm{~mm} \times 1 \mathrm{~mm})$ used as the anode. Graphite rod $(7 \times 70 \mathrm{~mm})$ used as the counter electrode cathode. Before mounting the substrates in the cell, they are cleaned sonically using organic cleaner and aqueous solvents (ethanol, acetone, chloroform, de-ionized water) Sequentially, and each cleaning step duration is 5 minutes. The applied d.c.

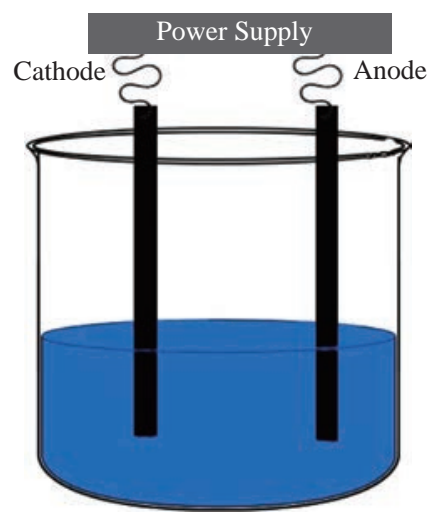

Fig. 1 The electrochemical cell.
The voltage between the electrodes is $15 \mathrm{~V}$ under a current density of $9.22 \times 10^{-3} \mathrm{~mA} / \mathrm{cm}^{2}$ for $8 \mathrm{~h}$, A brawn precipitate has obtained, and the product has been washed with de-ionized water and dried overnight to subsequent analysis.

\section{Antibacterial assay}

The $\alpha-\gamma \mathrm{Al}_{2} \mathrm{O}_{3}$ nanocomposite synthesized using the electrolysis method. The nanocomposite was tested for antibacterial activity by agar disc diffusion method against bacillus anthrax, then incubated at $37^{\circ} \mathrm{C}$ for 24 h. Finally, the inhibition zone of bacteria was measured at different levels.

\section{Results and Discussion}

Fig. 2 shows X-ray diffraction patterns of $\alpha-\gamma \mathrm{Al}_{2} \mathrm{O}_{3}$ nanocomposite powders. It observes six crystalline peaks of $\gamma-\mathrm{Al}_{2} \mathrm{O}_{3}$, which have miller indices (220) (311) (222) (400) (511) and (440) [38], and five crystalline peaks of $\alpha-\mathrm{Al}_{2} \mathrm{O}_{3}$, also have miller indices (012) (311) (024) (122) and (128) [39]. The crystalline size of $\alpha-\gamma$ $\mathrm{Al}_{2} \mathrm{O}_{3}$ nanocomposite has been calculated by using Scherer's formula $(\mathrm{D}=0.9 \lambda / \mathrm{B} \cos \theta)[40]$. The mean crystallite size of nanoparticles was $9.1 \mathrm{~nm}$, while the (222) reflection peak indicated the formation of

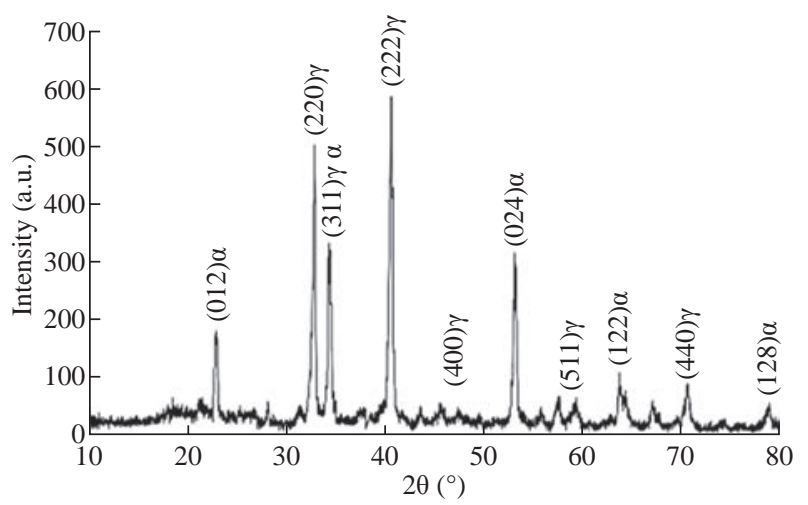

Fig. 2 XRD pattern of $\alpha-\gamma \mathrm{Al}_{2} \mathrm{O}_{3}$ nanocomposite.

$\gamma-\mathrm{Al}_{2} \mathrm{O}_{3}$

The morphology of $\alpha-\gamma \mathrm{Al}_{2} \mathrm{O}_{3}$ nanocomposite powders has been characterized by transmission electron microscopy (TEM) in Fig. 3. The size of the nanocomposite is apparent with a size of less than 10 $\mathrm{nm}$. The agglomeration of more nodular individual particles has existed in the structure of nanocomposite. Most of the particles have rough surface morphology.

Fig. 4 shows the inhibition zone, which indicates the nanocomposite of $\alpha-\gamma \mathrm{Al}_{2} \mathrm{O}_{3}$ shows the strong 

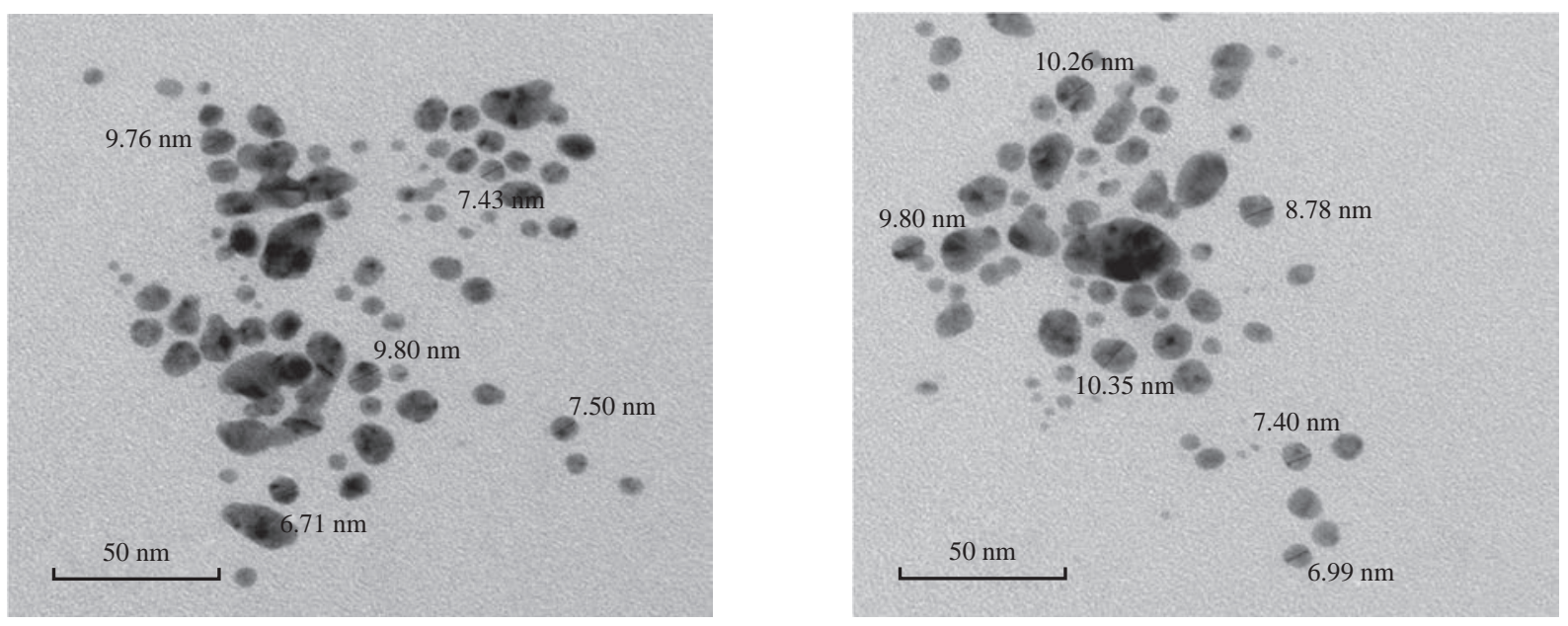

Fig. 3 TEM images of $\alpha-\gamma \mathrm{Al}_{2} \mathrm{O}_{3}$ nanocomposite at different locations.
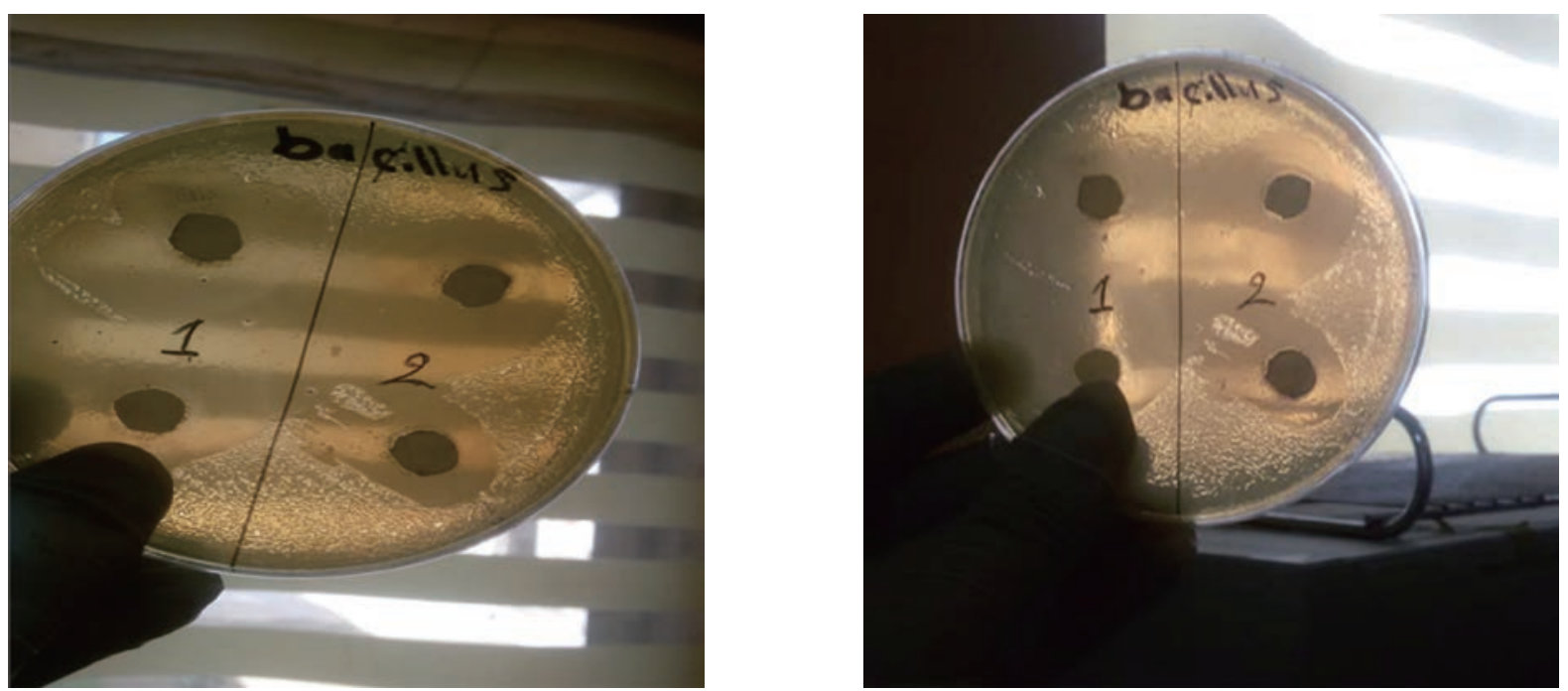

Fig. 4 The inhibition zone of bacterial growth on agar plates by using $\alpha-\gamma \mathrm{Al}_{2} \mathrm{O}_{3}$ nanocomposite as antibacterial.

effect against gram-negative bacteria type bacillus anthrax. Hence, the results demonstrate that the $\alpha-\gamma$ $\mathrm{Al}_{2} \mathrm{O}_{3}$ nanocomposite promising antimicrobial agents against bacteria. The activity of nanoparticles against bacteria has been reported by several studies that were obtained the mechanism of the bactericidal effect of nanoparticles is not understood wholly. It may be the nanoparticle attack to surface membrane. Many changes took place in its membrane morphology and disturb its power function, such as permeability, produced an essential increase in its permeability, affecting suitable transport through the membrane of plasma, resulting in cell death. It can be that the penetration of nanoparticle inside bacteria causing damage via interaction with Sulphur and phosphorous having compounds such as DNA. It can vanish its replication ability, and cellular proteins convert an inactive after the treatment of nanoparticle. In this project, the strong activity of $\mathrm{Al}_{2} \mathrm{O}_{3}$ due to the small size of the nanoparticles provides good penetration of the nanoparticles inside the cell then caused many changes later cell death [1, 14, 16, 41].

\section{Conclusions}

$\alpha-\gamma \mathrm{Al}_{2} \mathrm{O}_{3}$ nanocomposite was synthesized by electrolysis method, which was a simple and efficient method for preparing $\alpha-\gamma \quad \mathrm{Al}_{2} \mathrm{O}_{3}$ nanocomposite. The prepared nanocomposite was characterized using X-ray diffraction analysis, field emission scanning electron microscopy, and transmission electron microscopy, which displayed that the as-prepared sample had the size of $\alpha-\gamma$ $\mathrm{Al}_{2} \mathrm{O}_{3}$ nanocomposite less than $10 \mathrm{~nm}$. In addition, $\alpha-\gamma \mathrm{Al}_{2} \mathrm{O}_{3}$ nanocomposite showed a strong activity against bacteria, and this activity was influenced by the size of nanoparticles due to which they could easily reach the nuclear content of bacteria. The nanoparticles presented large and impressive surface area; thus, the contact with bacteria was 
the greatest, which could be the reason behind the strong activity against bacteria, and that smaller particles made large inhibition zones.

\section{Acknowledgments}

We gratefully acknowledge the Faculty of Chemistry at Wasit University for supporting this work.

\section{References}

[1] A.H. Ismail, H.K. Al-Bairmani, Z.S. Abbas, et al., Nanoscale synthesis of metal (II) theophylline complexes and assessment of their biological activity. Nano Biomed. Eng., 2020, 12(2): 139-147.

[2] H.I. Abdulah, D.H. Hussain, and A.M. Rheima, Synthesis of $\alpha-\mathrm{Fe}_{2} \mathrm{O}_{3}, \gamma-\mathrm{Fe}_{2} \mathrm{O}_{3}$ and $\mathrm{Fe}_{3} \mathrm{O}_{4}$ nanoparticles by electrochemical method. Journal of Chemical. Biological and Physical Sciences, 6(4): 1288-1296.

[3] M.A. Mohammed, A.M. Rheima, S.H. Jaber, et al., The removal of zinc ions from their aqueous solutions by $\mathrm{Cr}_{2} \mathrm{O}_{3}$ nanoparticles synthesized via the UV-irradiation method. Egyptian Journal of Chemistry, 2020, 63(2): 5-6.

[4] A.M. Rheima, M.A. Mohammed, S.H. Jaber, et al., Inhibition effect of silver-calcium nanocomposite on alanine transaminase enzyme activity in human serum of Iraqi patients with chronic liver disease. Drug Invention Today, 2019, 12(11): 2818-2821

[5] A.A. Ali, R.M. Al-Hassani, D.H. Hussain, et al., Synthesis, spectroscopic, characterization, pharmacological evaluation, and cytotoxicity assays of novel nano and micro scale of copper (II) complexes against human breast cancer cells. Drug Invention Today, 2020; 14(1): 31-39.

[6] D.H. Hussain, H.I. Abdulah, and A.M. Rheima, Synthesis and characterization of $\gamma-\mathrm{Fe}_{2} \mathrm{O}_{3}$ nanoparticles photo anode by novel method for dye sensitized solar cell.International Journal of Scientific and Research Publications, 2016, 6(10): 26-31.

[7] S.H. Jabber, D.H. Hussain, A.M. Rheima, et al., Comparing study of $\mathrm{CuO}$ synthesized by biological and electrochemical methods for biological activity. AlMustansiriyah Journal of Science, 2019, 30(1): 94-98.

[8] A.H. Ismail, H.K. Al-Bairmani, Z.S. Abbas, Synthesis, characterization, spectroscopic, and biological activity studies of nano scale $\mathrm{Zn}$ (II), Mn (II) and Fe (II) theophylline complexes. Journal of Xi'an University of Architecture \& Technology, 2020, XII(II): 2775-2789.

[9] A.M. Rheima, D.H. Hussain, and H.I. Abdulah, Silver nanoparticles: Synthesis, Characterization and their used a counter electrodes in novel Dye sensitizer solar cell. IOSR Journal of Applied Chemistry, 2016, 9(10): 6-9.

[10] A.A. Ali, R.M. Al-Hassani, D.H. Hussain, et al., Fabrication of solar cells using novel micro - and nano complexes of triazole Schiff base derivatives. Journal of Southwest Jiaotong University, 2019, 54(6): 1-19

[11] A.M. Rheima, D.H. Hussain, and M.M.A. Almijbilee, Graphene-silver nanocomposite: synthesis, and adsorption study of cibacron blue dye from their aqueous solution. Journal of Southwest Jiaotong University, 2019, 54(6): 1-6

[12] A.M. Rheima, M.A. Mohammed, S.H. Jaber, et al.Adsorption of selenium $\left(\mathrm{Se}^{4+}\right)$ ions pollution by pure rutile titanium dioxide nanosheets electrochemicallysynthe sized. Desalination and Water Treatment. 2020, 194: 187-193.
[13] H.A. Kadhum, W.M. Salih, A.M. Rheima. Improved PSi/ c-Si and $\mathrm{Ga} / \mathrm{PSi} / \mathrm{c}-\mathrm{Si}$ nanostructures dependent solar cell efficiency. Applied Physics A. 2020 Oct; 126(10): 1-5.

[14] A.M. RHEIMA, N.A. ABOUD, B.E. JASIM, A.H. ISMAIL, Z.S. ABBAS. Synthesis and structural characterization of $\mathrm{ZnTiO}_{3}$ nanoparticles via modification sol-gel prosses for assessment of their antimicrobial activity. International journal of pharmaceutical research. 2021, 13(1): 342-347.

[15] A.H. Ismail, H.K. AL-Bairmani, Z.S. Abbas, et al. Synthesis, Characterization, Spectroscopic and Biological Studies of Zn (II), Mn (II) and Fe (II) Theophylline Complexes in Nanoscale. Nano Biomed. Eng. 2020 Jul 1; 12(3): 253-261.

[16] N.A. Jasim, F. A. Al-Gasha’a, M.F. Al-Marjani, et al., $\mathrm{ZnO}$ nanoparticles inhibit growth and biofilm formation of vancomycin-resistant S. aureus (VRSA). Biocatalysis and Agricultural Biotechnology. 2020 Oct 1; 29: 101745.

[17] A.H. Ismail, H.K. Al-Bairmani, Z.S. Abbas, A.M. Rheima. Nano metal-complexes of theophylline derivative: synthesis, characterization, molecular structure studies, and antibacterial activity. InIOP Conference Series: Materials Science and Engineering, 2020 Nov 1 (Vol. 928, No. 5, p. 052028). IOP Publishing.

[18] N.A. Aboud, W.H. Alkayat, D.H. Hussain, A.M. Rheima. A comparative study of $\mathrm{ZnO}, \mathrm{CuO}$ and a binary mixture of $\mathrm{ZnO0.5-CuO0.} 5$ with nano-dye on the efficiency of the dye-sensitized solar cell. InJournal of Physics: Conference Series 2020 Nov 1 (Vol. 1664, No. 1, p. 012094). IOP Publishing.

[19] A.H. Rheima, D.H. Hussain, H.J. Abed. Fabrication of a new photo-sensitized solar cell using $\mathrm{TiO}_{2} / \mathrm{ZnO}$ Nanocomposite synthesized via a modified sol-gel Technique. InIOP Conference Series: Materials Science and Engineering, 2020 Nov 1 (Vol. 928, No. 5, p. 052036). IOP Publishing.

[20] A. Rheima, A.A. Anber, A. Shakir, A. Salah Hammed, S. Hameed. Novel method to synthesis nickel oxide nanoparticles for antibacterial|' activity. Iranian Journal of Physics Research. 2020 Nov 21; 20(3): 51-55.

[21] P.S. Haddad, A.B. Seabra, Biomedical applications of magnetic nanoparticles. Iron oxides: Structure, properties and applications. Nova Science Publishers, 2012: 165188.

[22] L.L. Hench, Bioceramics: From concept to clinic. J Am Ceram Soc, 1991, 74: 1487-1510.

[23] A.M. Rheima, Synthesis of silver nanoparticles using the uv-irradiation technique in an antibacterial application. Journal of Southwest Jiaotong University, 2019, 54(5): 1-5

[24] P. Ganguly, J.P. Warren. In situ measurement of reinforcement stress in an aluminium-alumina metal matrix composite under compressive loading. Mater Sci Eng., 2003, 352: 46-54.

[25] D.H. Hussain, A.M. Rheima, and S.H. Jaber, Cadmium ions pollution treatments in aqueous solution using electrochemically synthesized gamma aluminum oxide nanoparticles with DFT study. Egyptian Journal of Chemistry, 2020, 63(2): 417-424.

[26] L.A. Xue, I.W. Chen, Influence of additives on $\gamma$ - to- $\alpha$ transformation of alumina. Journal of Materials Science Letters, 1992, 11(8): 443-445.

[27] K. Oberlander, Applied industrial catalysis. Academic Press, 1984: 63.

[28] K. Wefers, Alumina chemicals: Science and technol-ogy handbook.The American Ceramic Society, 1990: 13.

[29] H. Youn, J.W. Jang, I. Kim, et al., Low-temperature formation of $\alpha$-alumina by doping of an alumina-sol. Journal of Colloid and Interface Science, 1999, 211(1): 110-113.

[30] H.Y. Zhu, J.D. Riches, and J.C. Barry, A-alumina 
nanofibers prepared from aluminum hydrate with poly(ethylene oxide) surfactant. Chemistry of Materials, 2002, 14(5): 2086-2093.

[31] S. Bhaduri, E. Zhou, and S.B. Bhaduri, Auto ignition processing of nanocrystalline $\alpha-\mathrm{Al}_{2} \mathrm{O}_{3}$. Nanostructured Materials, 1996, 7(5): 487-496.

[32] S. Bhaduri, S.B. Bhaduri, and E. Zhou, Auto ignition synthesis and consolidation of $\mathrm{Al}_{2} \mathrm{O}_{3}-\mathrm{ZrO}_{2}$ nano/nano composite powders. Journal of Materials Research, 1998, 13(1): 156-165.

[33] K.C. Patil, S.T. Aruna, and S. Ekambaram, Combustion synthesis. Current Opinion in Solid State \& Materials Science, 2(2), 1997: 158-165.

[34] C.B. Reid, J.S. Forrester, H.J. Goodshaw, et al., A study in the mechanical milling of alumina powder. Ceramics International, 2008, 34(6): 1551-1556.

[35] F. Mirjalili, M. Hasmaliza, and L.C. Abdullah, Sizecontrolled synthesis of nano $\alpha$-alumina particles through the solgel method. Ceramics International, 2010, 36(4): 1253-1257.

[36] R. Kavitha, V. Jayaram, Deposition and characterization of alumina films produced by combustion flame pyrolysis. Surface and Coatings Technology, 2006, 201(6): 24912499.
[37] D.H. Trinh, M. Ottosson, M. Collin, et al., Nanocomposite $\mathrm{Al}_{2} \mathrm{O}_{3}-\mathrm{ZrO}_{2}$ thin films grown by reactive dual radiofrequency magnetron sputtering. Thin Solid Films, 2008, 516(15): 4977-4982.

[38] L. Qu, C. He, Y. Yang, et al., Hydrothermal synthesis of alumina nanotubes templated by anionic surfactant. Materials Letters, 2005, 59(29-30): 4034-4037.

[39] JCPDS No. 29-0063, 83-2080 Decker, General Electric Co., Schenectady, NY, USA, Private Communication, 2008.

[40] B.D. Cullity, Elements of X-ray diffraction, $2^{\text {nd }}$ edition. Addison-Wesley, 1978: 102.

[41] A.H. Ismail, H.K. Al-Bairmani. Nano-synthesis, spectroscopic characterisation and antibacterial activity of some metal complexes derived from theophylline. Egyptian Journal of Chemistry, 2020, 63(12): 4951-4962

Copyright $₫$ Ahmed Mahdi Rheima, Ahmed Abed Anber, Hussein Ismael Abdullah, and Ahmad Hussein Ismail. This is an open-access article distributed under the terms of the Creative Commons Attribution License, which permits unrestricted use, distribution, and reproduction in any medium, provided the original author and source are credited. 